\title{
The Intertextuality of Animal Metaphors in Rendra's Poems and the Bible
}

\author{
Wadji \\ \{wadji@unikama.ac.id $\}$
}

Universitas Kanjuruhan Malang, Malang, Indonesia

\begin{abstract}
One of the interesting things about poems is that they are rich in metaphors. In addition to beautifying expressions in literary works, metaphors have a function to enhance imagination. Rendra was known as a poet who was good at building metaphors in his poems. The purpose of this paper was to describe the influence of biblical metaphors on Rendra's poetry works, especially animal metaphors. The approach used in this study was an intertextuality approach in the perspective of Gerald Genette and Michael Riffaterre. The results of the analysis showed that Rendra's poems in the romantic period, namely the poems collected in the books Ballada Orang-Orang Tercinta and Blues untuk Bonnie, have a tendency to be influenced by animal metaphors from the Bible, both the Old and New Testaments. In Indonesian culture, there was almost no comparison of the female with the likes of a deer or reindeer, for example. Meanwhile, the words deer and reindeer occur frequently in the Bible, some of which have the meaning of the female body.
\end{abstract}

Keywords: Rendra, Bible, metaphor, intertextuality

Intertekstualitas Metafora Binatang dalam Sajak-sajak Rendra dan Alkitab

\begin{abstract}
Abstrak. Salah satu yang menarik dari puisi adalah kaya akan metafora. Selain memperindah ekspresi dalam karya sastra, metafora memiliki fungsi untuk meningkatkan imajinasi. Rendra dikenal sebagai penyair yang pandai membangun metafora dalam puisinya. Tulisan ini bertujuan untuk mendeskripsikan pengaruh metafora alkitabiah dalam puisi karya Rendra, khususnya metafora binatang. Pendekatan yang digunakan dalam penelitian ini adalah pendekatan intertekstualitas dalam perspektif Gerald Genette dan Michael Riffaterre. Hasil analisis menunjukkan bahwa puisi Rendra pada masa romantisme, yaitu puisi yang terkumpul dalam buku Ballada Orang-Orang Tercinta dan Blues untuk Bonnie, cenderung dipengaruhi oleh metafora binatang dari Alkitab, baik Perjanjian Lama maupun Baru. Dalam budaya Indonesia hampir tidak ada perbandingan antara tubuh perempuan seperti rusa atau kijang, misalnya. Sementara itu kata rusa dan rusa kutub sering muncul dalam Alkitab, beberapa di antaranya memiliki arti tubuh perempuan.
\end{abstract}

Kata kunci: Rendra, Alkitab, metafora, intertekstualitas. 


\section{Pendahuluan}

Penelitian tentang metafora telah banyak dilakukan, baik metafora dalam karya sastra maupun metafora dalam kitab suci. Manusia adalah hewan yang bersastra, berevolusi, dan memiliki kecenderungan untuk bercerita tentang binatang yang berhubungan dengan kehidupannya sendiri [1]. Semua kitab suci, baik kitab suci agama-agama Semitik maupun agama-agama non-Semitik, ditulis dengan bahasa sastra yang indah. Firman Tuhan tidak hanya disampaikan dalam bahasa yang lugas saja, tetapi juga melalui bahasa simbolik. Kitab suci telah menginspirasi banyak penulis puisi dan fiksi di berbagai negara. Banyak karya sastra tanpa disadari merupakan bentuk tafsir atas kitab suci tertentu.

Rendra adalah penyair Indonesia terbesar setelah Chairil Anwar. Karya-karya puisi Rendra sangat kaya akan metafora. Sebagai seorang penyair yang lahir dan berpendidikan Katolik, Rendra tentunya tidak bisa dilepaskan dari tradisi kitab suci, baik Perjanjian Lama maupun Perjanjian Baru. Selama ini publik sastra banyak yang meyakini bahwa sumber gagasan dan ekspresi Rendra banyak dipengaruhi oleh penyair Spanyol Frederic Garcia Lorca, sebagaimana dikemukakan oleh Subagio Sastrowardojo [2]. Namun dalam penelitian ini, dengan menggunakan pendekatan intertekstualitas, penulis membuktikan bahwa metaforametafora, terutama metafora binatang, dalam karya-karya Rendra memiliki hipogram pada Alkitab.

Teori intertekstualitas mula-mula diperkenalkan oleh Julia Kristeva, kemudian dikembangkan oleh penerusnya dalam banyak varian. Intertekstualitas Genette, misalnya, sangat berbeda dengan Kristeva dan pascastrukturalis lainnya. Genette [3] mengembangkan apa yang disebut dengan strukturalisme pragmatik atau strukturalisme terbuka. Dalam Palimsestes, Genette [4] meminta globalitas gagasan tentang transtekstualitas dan menawarkan lima subkategori: intertekstualitas, paratekstualitas, metatekstualitas, arkitekstualitas (architextuality), dan hipertekstualitas. Riffaterre [5] mengajukan dua aksioma: bahwa signifikasi puitik adalah tidak langsung — sebuah sajak mengatakan sesuatu dan tujuan yang lain - dan bahwa unit makna dalam sajak adalah entitas teks terbatas dan tertutup. Membaca sebuah sajak adalah sebuah percarian untuk kesatuan, dan kesatuan dicapai dan dirasakan hanya ketika pembaca melepaskan makna referensial yang jelas atau representasional dari wacana dan memegang penyatuan utama atau faktor yang pelbagai tanda sajak menyatakannya dengan tidak langsung.

Studi tentang metafora binatang telah banyak dilakukan oleh para peneliti. Benjamin A. Foreman [6] melakukan penelitian tentang metafora binatang dalam salah satu kitab dalam Alkitab Perjanjian Lama, yakni Kitab Yeremia. Penelitian metafora binatang dilakukan juga oleh Kathleen Robin Hart [7] dengan judul penelitian Animal Humor and the Darwinian. Zahra Jafari [8] melakukan penelitian tentang metafora binatang terhadap karya William Shakespeare, King Lear. Rachmat Djoko Pradopo [9] pernah mengaji metafora sajak-sajak Rendra dalam penelitiannya tentang stilistika genetik, dengan objek penelitian Ballada Orangorang Tercinta dan Blues untuk Bonnie.

Penelitian metafora binatang atas sajak-sajak Rendra, terlebih lagi kaitannya dengan Alkitab, sejauh ini belum dilakukan baik oleh peneliti dalam negeri maupun luar negeri. OLeh karena itu, dalam penelitian ini akan dibahas (a) metafora binatang dalam Alkitab, (b) metafora binatang dalam sajak-sajak Rendra, kemudian (c) intertekstualitas metafora binatang dalam sajak-sajak Rendra dan Alkitab. 


\section{Metode}

Untuk mengungkap keterkaitan sajak-sajak Rendra dengan Alkitab, penelitian ini menggunakan pendekatan intertekstualitas. Alkitab menjadi sumber inspirasi bagi banyak penulis, baik fiksi maupun nonfiksi. Intertekstualitas diperkenalkan dalam studi Alkitab sejak tahun 1989. Mula-mula intertekstualitas hanyalah untuk mengaji kaitan antara Perjanjian Lama dan Perjanjian Baru [10]. Pendekatan intertekstualitas pertama kali diperkenalkan oleh Julia Kristeva.

Metode penelitian ini adalah deskriptif-kualitatif. Sumber data dalam penelitian ini adalah Alkitab dan sajak-sajak Rendra. Alkitab yang digunakan adalah Alkitab terjemahan bahasa Indonesia oleh Lembaga Alkitab Indonesia [11]. Sajak-sajak Rendra yang menjadi sumber data dalam penelitian ini adalah sajak-sajak Rendra dalam kumpulan puisi Ballada Orangorang Tercinta [12] dan Blues untuk Bonnie [13]. Teknik analisis data dalam penelitian ini dengan mengikuti beberapa tahapan. Pertama, melakukan pembacaan mimetik dan retroaktif. Selanjutnya, menganalisis masing-masing teks yang diikuti dengan membandingkan dua teks yang memiliki latar budaya dan waktu berbeda tersebut. Untuk menguji kesahihan data, peneliti melakukan studi yang mendalam serta melakukan diskusi dengan teman sejawat.

Tidak semua pasal dan ayat dalam Alkitab dianalisis dalam penelitian ini. Hanya ayatayat yang berisi kritik sosial yang dipilih untuk dianalisis. Begitu pula dengan sajak-sajak Rendra, hanya sajak-sajak yang berisi metafora binatang yang dipilih untuk dianalisis. Langkah selanjutnya adalah menyejajarkan ayat-ayat Alkitab dan sajak-sajak Rendra yang memiliki hubungan intertekstualitas metafora binatang.

\section{Hasil dan Pembahasan}

\subsection{Metafora Binatang dalam Alkitab}

Dalam Alkitab, baik Perjanjian Lama maupun Perjanjian Baru, terdapat banyak sekali jenis binatang. Binatang-binatang dalam Alkitab ada yang memiliki makna denotasi, ada juga konotasi. Dalam kaitannya dengan makna simbolis, kehadiran binatang dalam Alkitab selalu berhubungan dengan sifat dan perilaku manusia. Hal ini dikaitkan dengan bentuk fisik, suara, dan perilaku binatang tertentu yang diidentikkan dengan perilaku dan karakter manusia.

Binatang-binatang yang menjadi objek metafora yang paling menonjol dalam Alkitab adalah kijang, rusa, kuda, burung, dan ular. Dalam Kitab Kejadian "ular" adalah simbol kejahatan, yakni sebagai representasi Iblis yang menggoda manusia di Taman Eden. Selaras dengan Kitab Kejadian, "ular" dalam Ulangan 33:32, "Air anggur mereka adalah racun ular, dan bisa ular tedung yang keras ganas," juga dihubungkan dengan kejahatan. Ular juga dihubungkan dengan nubuat penderitaan Yesus di kayu salib, sebagaimana dalam Bilangan 21:9 berikut ini:

Lalu Musa membuat ular tembagadan menaruhnya pada sebuah tiang; maka jika seseorang dipagut ular, dan ia memandang kepada ular tembaga itu, tetaplah ia hidup.

Dalam Perjanjian Baru, kata "ular" juga ditemukan dengan konotasi negatif. Dalam Matius 23:32 Yesus menggunakan perumpamaan "ular" bagi para pemuka agama dan imamimam palsu yang menolak firman Tuhan dan menggantikannya dengan gagasan pribadinya.

Hai kamu ular-ular, hai kamu keturunan ular beludak! Bagaimanakah mungkin kamu dapat meluputkan diri dari hukuman neraka? 


\subsection{Metafora Binatang dalam Sajak-Sajak Rendra}

Rendra sangat dikenal sebagai penyair yang pandai membangun metafora, termasuk metafora binatang. Metafora binatang yang menonjol dalam sajak-sajak Rendra antara lain adalah kijang, burung, kuda, dan ular. Dalam sajak "Ballada Terbunuhnya Atmo Karpo," misalnya, Rendra mengulang-ulang kata "kuda" sebagai simbol kekuatan dan kejantanan. Kuda identik dengan kekerasan dan perang. Bagi Rendra kuda juga menggambarkan nafsu perempuan, sebagaimana dalam kutipan sajak "Kepada MG" berikut ini:

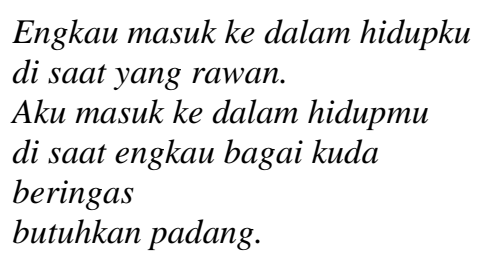

Dalam banyak tradisi, burung identik dengan kematian. Burung gagak adalah simbol kematian, burung hantu identik dengan sihir, burung merpati melambangkan kesetiaan. Dalam sajak-sajak Rendra, burung selalu bercitra negatif: berita kemalangan, duka, dan dendam. Dalam "Ballada Sumilah," misalnya, Rendra menggunakan metafora burung untuk menyampaikan kabar duka.

Bila dukana terkaca pada bulan keramik putih

antara bebatang jati dengan rambut tergerai

Sumilah yang malang mendamba Samijonya

menyuruk musang, burung gantil nyanyikan ballada hitam.

Sementara itu, dalam "Ballada Ibu yang Dibunuh" Rendra menggunakan "burung kolik" sebagai simbol kemarahan dan dendam.

Burung kolik menyanyikan berita panas dendam warga desa menggetari ujung bulu-bulunya tapi dikibaskannya juga.

\subsection{Intertekstualitas Metafora Binatang dalam Sajak-sajak Rendra dan Alkitab}

Teks sastra, menurut Kristeva [14], sebagai seperangkat translinguistik yang membagibagi kembali susunan bahasa, sebagai suatu ruang dengan beberapa ucapan yang diambil dari teks-teks lain, bersilang dan menetralisir satu sama lain. Menurut Riffaterre [15] intertekstualitas dapat menjelaskan apa yang tak terkatakan oleh sebuah teks. Pembaca harus berhipotesis dan mencari mata rantai yang hilang dari teks tersebut. Gerald Genette [16] menyatakan bahwa intertekstualitas merupakan relasi kehadiran bersama antara dua atau lebih teks, di mana satu teks hadir secara efektif dalam teks lain dalam bentuk plagiarisme, quotasi, atau alusi.

Sekali pun dalam budaya Indonesia tidak lazim membandingkan tubuh dengan seekor kijang atau rusa, tetapi Rendra menerobos banyak hal yang dianggap tabu. Dalam karya sastra Indonesia dan juga sastra daerah di Nusantara, lazimnya perbandingan tubuh perempuan adalah dengan tumbuh-tumbuhan. Perbandingan dengan binatang dianggap sebagai pelecehan atau bahkan penghinaan. Sedikit contoh dalam penelitian ini diharapkan mewakili hasil penelitian tentang bagaimana Rendra menggunakan metafora binatang dalam sajak-sajaknya, termasuk dalam mencirikan tubuh perempuan. Dalam "Nyanyian Duniawi," Rendra berhasil memopulerkan metafora binatang ini: 
Di dalam bayangan pohon-pohon

tubuhnya bercahaya

bagaikan kijang kencana.

Membandingkan tubuh perempuan dengan kijang tidak asing lagi dalam Perjanjian Lama. Dalam kasus ini, setidaknya sajak Rendra di atas mendapatkan pengaruh dari Kidung Agung 2:8-9 seperti tertulis di bawah ini:

Dengarlah! Kekasihku! Lihatlah, ia datang, melompat-lompat di atas gunung-gunung, meloncat-loncat di atas bukit-bukit. Kekasihku serupa kijang, atau anak rusa.

Jika dalam sajak Rendra kata "kuda" yang bermakna kemegahan, kekuatan, dan kekuasaan disandingkan dengan "kutukan," maka ketika kita membaca Alkitab dan menemui gejala semacam, tampaknya pembaca tidak akan mengatakan bahwa hal tersebut merupakan peristiwa yang kebetulan. Dalam Hakim-Hakim:22-23, misalnya, kita dapati teks berikut ini:

Ketika itu menderaplah telapak kuda, karena berpacu lari kuda-kudanya. "Kutukilah kota Meros!" firman Malaikat TUHAN, "kutukilah habis-habisan penduduknya, karena mereka tidak datang membantu TUHAN, membantu TUHAN sebagai pahlawan."

Bandingkan dengan kutipan sajak Rendra yang berjudul "Ballada Terbunuhnya Atmo Karpo" berikut ini:

Dengan kuku-kuku besi kuda menebah perut bumi

Bulan berkhianat gosok-gosokkan tubuhnya di pucuk-pucuk para

Mengepit kuat-kuat lutut menunggang perampok yang diburu

Surai bau keringat basah, jenawi pun telanjang

Segenap warga desa mengepung hutan itu

Dalam satu pusaran pulang balik Atmo Karpo

Mengutuki bulan betina dan nasibnya yang malang

Berpancaran bunga api, anak panah di bahu kiri

Dalam Alkitab, kata "ular" sebagian besar berkonotasi negatif, sebagaimana dalam Alkitab Perjanjian lama dan Perjanjian Baru. Dalam banyak latar budaya, ular memiliki citra positif, setidaknya dalam budaya India dan Cina. Ular sudah terlanjur menempel pada citra perempuan, setidaknya pada peristiwa jatuhnya manusia dari Taman Eden. Citra "ular" yang negatif dan sebagai representasi Iblis oleh Rendra juga disandingkan dengan perempuan, misalnya dalam sajak Aminah berikut ini.

Juga sudah terbayangkan olehnya

salah satu bunda cerita pada putranya:

"Jauhi Aminah!

Kalau bunga, ia bunga bangkai.

Kalau buah, ia buah maja.

Ia adalah ular beludak.

Ia adalah burung malam.

Begini ceritanya:

Dulu ia adalah bunga desa

ia harum bagai mawar

tapi sombong bagai bunga mentari. 
Rendra banyak menggunakan kata "ular" dalam membangun citra negatif terhadap perempuan dan segala tingkah laku yang tidak menyenangkan.

\section{Simpulan}

Metafora binatang yang dibangun Rendra pada karya-karya sajaknya dalam kumpulan puisi Ballada Orang-orang Tercinta dan Blues untuk Bonnie hipogramnya adalah Alkitab, baik Perjanjian Lama maupun Perjanjian Baru. Banyak metafora Rendra yang tidak lazim dalam tradisi sastra Indonesia, terutama metafora binatang, karena metafora-metafora Rendra adalah hasil pengukuhan Rendra terhadap tradisi, yakni tradisi dalam kitab suci. Penelitian ini diharapkan berkontribusi bagi pengembangan kajian sastra, terutama terhadap sajak-sajak Rendra yang selama ini lebih banyak dilihat dari sisi kritik sosialnya. Oleh karenanya, peneliti mengundang peneliti lain untuk menindaklanjuti rintisan penelitian ini.

\section{Referensi}

[1] Hart, KR, Long Jr, John H. Animal Metaphors and Metaphorizing Animals: An Integrated Literary, Cognitive, and Evolutionary Analysis of Making and Partaking of Stories. Evo Edu Outreach. 2011.Vol. 4. Pp. 52-63.

[2] Sastrowardojo S. Sosok Pribadi dalam Sajak. Jakarta: Balai Pustaka. 1997. Kerancuan Pribadi Rendra-Lorca. pp. 159-201.

[3] Allen G. Intertextuality. London: Routledge. 2000. Pp. 73

[4] Alfaro MJM. Intertextuality: Origins and development of the concept. Atlantis Vol. 18 No. 1/2 1996, 268-285.

[5] Culler, J. (2005). The persuit of signs. London: Routledge, pp. 89

[6] Foreman, BA. Animal Metaphors and the People of Israel in the Book of Jeremiah. Göttingen: Vandenhoeck \& Ruprecht GmbH \& Co. KG. 2011.

[7] Hart KR. Animal Humor and the Darwinian Absurd. Contemporary French and Francophone Studies Volume 16, 2012 - Issue 4: Human - Animal Part 1. pp. 477-485.

[8] Jafari Z. Metaphorize Animals: An Investigation of Animal Metaphor in King Lear. Uluslararasi Sosyal Araştırmalar Dergisi, The Journal of International Social Research Cilt: 7 Sayı: 32 Volume: 7 Issue: 32. www.sosyalarastirmalar.com Issn: 1307-9581. 2002. 418-431.

[9] Pradopo DR. Penelitian Stilistika Genetik: kasus Gaya Bahasa W.S. Rendra dalam Ballada Oranforang Tercinta dan Blues untuk Bonnie. Humaniora. No.12. September-Desember. pp. 94-101.

[10] Moyise S. Intertextuality and Biblical Studies: A Review. Verbum Et Ecclesia JRG 23(2). pp. 418 431.

[11] Alkitab. Lembaga Alkitab Indonesia. 2001.

[12] Rendra. Ballada Orang-orang Tercinta. Jakarta: Pustaka Jaya. Cetakan ke-7. 1993.

[13] Rendra. Blues untuk Bonnie. Jakarta: Pustaka Jaya. Cetakan ke-6. 1993.

[14] Becker-Leckrone. (2013). Teori sastra dan Julia Kristeva. Denpasar: CV. Bali Media Adhikarsa.

[15] Riffaterre, M. Intertextuality vs. Hypertextuality. New Literary History. Vol. 25, No. 4, 25th Anniversary Issue. Part 2. Autumn, 1994. pp. 779-788. Published by: The Johns Hopkins University Press. Stable URL: http://www.jstor.org/stable/469373.

[16] Jefferson, A. Autobiography as intertext: Barthes, Sarraute, Robbe-Grillet. Michael Worton dan Judith Still. Intertextuality, theories and practices. Manchester University Press. 1990. 